\title{
SANKSI PIDANA TERHADAP PELAKU TINDAK PIDANA PENGGELAPAN DALAM SITUS JUAL BELI ONLINE
}

\author{
Made Rony Setiawan, A.A Sagung Laksmi Dewi, Ni Made Sukaryati Karma \\ Fakultas Hukum Universitas Warmadewa, Denpasar - Bali, Indonesia
}

\begin{abstract}
Abstrak
Pada dewasa ini dalam dunia transaksi elektronik banyak ditemukan perbuatan- perbuatan menyimpang, dan tidak berdasarkan pada norma hukum yang ada, dimana sebagian besar terjadi dalam sistem jual beli daring. Penjualan dan pembelian daring kadang hanya dilandasi oleh kepercayaan yang artinya pelaku perniagaan terkadang tidak jelas. Sehingga, penelitian ini dilaksanakan untuk mengetahui pengaturan hukum tentang perbuatan yang telah dilakukan oleh pelaku usaha kepada konsumen dan sanksi pidana yang dijatuhkan terhadap pelaku tindak pidana penggelapan dalam situs jual beli daring. Penelitian ini menggunakan metode normatif dikarenakan masih terdapat norma yang kabur, dengan bersumber pada pendapat para sarjana hukum dan UndangUndang. Larangan bagi pelaku usaha dalam kegiatan pemasaran diatur dalam Pasal 9 ayat 1 undang-undang Perlindungan Konsumen melarang pelaku usaha menawarkan, mempromosikan, mengiklankan suatu barang dan/atau jasa secara tidak benar atau seolah-olah barang tersebut telah memenuhi dan memiliki potongan harga, harga khusus, standar mutu tertentu, gaya atau mode tertentu, karakteristik tertentu, sejarah atau guna tertentu, barang tersebut dalam keadaan baik atau baru, barang dan jasa tersebut telah medapatkan atau memiliki sponsor, persetujuan, perlengkapan tertentu, keuntungan tertentu. Perbuatan pidana penggelapan berdasarkan ketentuan pasal 372 kuhp, dimana mengartikan seseorang yang mempunyai barang seseorang dengan maksud melanggar hukum merupakan perbuatan pidana penggelapan.
\end{abstract}

Kata Kunci: Sanksi Pidana, Penggelapan, Jual Beli online

\begin{abstract}
Nowadays in the world of electronic transactions many deviant acts are found, and are not based on existing legal norms, which mostly occur in the online trading system. Online sales and purchases are sometimes only based on trust, which means that the perpetrators of trade are sometimes unclear. Thus, this study was conducted to determine the legal arrangements regarding the actions that have been carried out by business actors to consumers and criminal sanctions imposed on perpetrators of embezzlement in online trading sites. This study uses a normative method because there are still vague norms, based on the opinions of legal scholars and the Law. Prohibition of business actors in marketing activities is regulated in Article 9 paragraph 1 of the Consumer Protection Act prohibiting business actors from offering, promoting, advertising goods and / or services incorrectly or as if the goods have fulfilled and have discounted prices, special prices, certain quality standards, certain styles or modes, certain characteristics, certain history or uses, the goods are in good or new condition, the goods and services have been obtained or have a sponsor, approval, certain equipment, certain benefits. Crimes of embezzlement are based on the provisions of article 372 KUHP, which means that someone who has someone's belongings with the intention of violating the law is an embezzlement.
\end{abstract}

Keywords: Criminal sanctions, embezzlement, buying and selling online

\section{PENDAHULUAN}

Diadakannya jual beli daring dimana hal tersebut melibatkan seorang penjual dan pembeli dalam arti lain pelaku usaha dan konsumen. Dimana pelaku usaha disebut sebagaikubu dalam yang menghasilkan suatu produk, jasa atau barang yang didistribusikan kepada konsumen dengan maksud agar mendapatkan keuntungan dan konsumen ialah kubu yang membutuhkan barang atau jasa dari produsen pada perjanjian bidang ekonomi.

Pikir bila suatu produk kurang sesuai dengan kondisinya. Semisalnya seorang ingin membeli modem merk terbaru dengan kecepatan yang tinggi di internet. Seluruh tetangga, kerabat, dan 
saudaranya tidak ada satupun yang mempunyai atau membeli modem merk tersebut sehingga pembeli tadi merasa modem tersebut terlalu tinggi kelasnya atau terlalu rendah kapasitasnya untuk dibeli, akibatnya transaksi pembeli pun dibatalkan (Unggul Pambudi, 2013). Kehadiran jejaring sosial juga semakin memperkuat kontrol sosial dalam pergaulan di internet. Testimoni dan rekomendasi dari pembeli sebelumnya memiliki pengaruh yang besar dalam membentuk perilaku pembeli apakah Akan memilih produk atau layanan jasa seseorang atau tidak. Dari percakapan timeline, kerapkali kita jumpai pembeli lama bisa dengan bebas menunjukkan kepuasan dan ketidakpuasan yang mereka dapatkan. Sesungguhnya yang dimaksud dengan jual beli yaitu menurut kamus besar Bahasa Indonesia jual beli merupakan persetujuan yang saling mengikat antara penjual, yakni pihak yang menyerahkan barang dan penerima barang yang dijual.

Jual beli dimasa yang serba digital tidaklah sama persis dengan dimasa sebelum digital, yang mana antara pembeli dengan pedagang bertemu secara langsung untuk melakukan transaksi. Pada era digital hal tersebut diganti dengan piranti teknologi sebagai perantara antara penjual dan pembeli, dengan tidak hanya menggunakan pembayaran tunai tetapi dengan pembayaran melaui $e$ money.

Rekening bersama yaitu model pembayaran transaksi yang berbeda dengan transfer bank, pada transfer bank pihak ketiga adalah banknya sedangkan dalam sistem ini pihak ketiga ialah badan usaha yang dipercaya penjual dan pembeli sebagai tempat transit transaksinya. Jual beli daringialahfasiltas yang menentukan tinggi serta rendahnya suatu perekenomian negara. Namun demikian, proses jual beli daring sangat tergantung pada kejujuran seorang penjual terhadap pembeli, apabila penjual melakukan suatu kecurangan dalam hal jual beli daring, maka dari itu dimana suatu kerugian sepenuhnya ditanggung oleh pembeli, dapat diperkirakan bahwa suatu sistem jual beli daring hampir rata-rata dipergunakan untuk menggelapkan barang atau benda seseorang.

Jual beli daring merupakan suatu perbuatan jual beli yang dilakukan pelaku usaha dengan konsumen untuk memenuhi suatu tujuan masing - masing dengan menggunaan system daring. Adapun jenis - jenis dari jual beli daring antara lain Transaksi melalui mini market adalah suatu transaksi yang paling sering digunakan dan populer dimana sering digunakan para penjual daring selain cukup mudah jenis transaksi ini juga memudahkan proses komfirmasi karena dana tersebut dapat dengan mudah dan cepat di cek oleh penerima dana atau penjual. Cash on delivery disini bisa di artikan sebagai suatu pertemuan antar pembeli dan penjual, dimana secara langsung si penjual menawarkan untuk bertemu di suatu tempat yang sudah di janjikan sebelumnya kepada si pembeli.

Adapun rumusan masalah yang di dapat, antara lain: Bagaimanakah pengaturan hukum tentang perbuatan yang telah dilakukan oleh pelaku usaha kepada konsumen dalam situs jual beli daring? Bagaimanakah sanksi pidana yang dijatuhkan terhadap pelaku tindak pidana penggelapan dalam situs jual beli daring? Penelitian ini bertujuan untuk mengetahui pengaturan hukum tentang perbuatan yang telah dilakukan oleh pelaku usaha kepada konsumen dan sanksi pidana yang dijatuhkan terhadap pelaku tindak pidana penggelapan dalam situs jual beli daring.

\section{METODE PENELITIAN}

Mengacu pada perumusan masalah, maka tipe penelitian yang digunakan dalam penulisan adalah penelitian normatif. Penelitian hukum normatif merupakan penelitian yang dilakukan dengan cara meneliti bahan pustaka atau data sekunder belaka (Soekanto and Mamudji 2018). Penelitian ini menggunakan pendekatan perundang-undangan (Statue approach), karena aspek yang akan diteliti adalah berbagai aturan hukum yang menjadi fokus sekaligus tema sentral suatu penelitian (Diantha 2016). Jenis bahan hukum yang digunakan dalam penelitian ini adalah bahan hukum primer yang terdiri dari Undang-Undang Dasar Negara Republik Indonesia Tahun 1945, Kitab Undang-Undang Hukum Pidana, Undang-Undang Republik Indonesia Nomor 8 Tahun 1999 tentang Perlindungan Konsumen, dan Undang-Undang Republik Indonesia Nomor 19 Tahun 2016 tentang Perubahan Atas UndangUndang Nomor 11 Tahun 2008 tentang Informasi dan Transaksi Elektronik Pasal 45A ayat (1). Bahan hukum sekunder yang berupa tulisan tentang hukum baik dalam bentuk buku ataupun jurnal-jurnal. Terakhir, bahan hukum tersier yang terdiri atas Kamus Besar Bahasa Indonesia, Kamus Hukum, dan media masa. Teknik pengumpulaan bahan hukum pada penelitian ini terdiri dari studi dokumentasi dan studi kepustakaan. 


\section{HASIL PENELITIAN DAN PEMBAHASAN}

\section{Pengaturan Hukum tentang Perbuatan yang telah Dilakukan oleh Pelaku Usaha kepada Konsumen dalam Situs Jual Beli Daring}

Lahirnya UUPK bisa menjadi dorongan yang kuat dan tanpa alasan, dimana kita ketahui dan tidak bisa dipungkiri lebih dari setengah tahun lamanya perekonomian kita masih dalam keadaan yang memprihatinkan. Setidaknya kerena perundang - undangan nasional yang hanya mengakui tiga pelaku utama atau subyek dalam perekonomian nasional, yaitu Badan Usaha Milik Negara, Koperasi dan perusahaan swasta. Bila hanya tiga pelaku utama yang dapat disebut sebagai subyek, maka tanpa dipertanyakan pun pastilah posisi konsumen memang hanyalah sebagai obyek atau bahkan memang konsumen bukanlah komunitas yang dapat diberi ruang - ruang prioritas. Larangan tersebut pada dasarnya mengusahakan agar produk diedarkan yang layak sesuai dengan informasi pengusaha (Syawali and Sri 2000).

Konsumen merupakan seluruh anggota dan keluarga yang mendapat jasa dan barang bisa untuk dikonsumsi secara pribadi (Kotler 2002). Menurut Hondius, para ahli hukum pada umumnya sepakat mengartikan konsumen sebagai, pemakai produksi terakhir dari benda dan jasa. Menurut BPHN (Badan Pembinaan Hukum Nasional) "Pemakai akhir dari barang, digunakan untuk keperluaan diri sendiri atau orang lain dan tidak diperjual belikan". Menurut YLKI (Yayasan Lembaga Konsumen Indonesia) Pemakai barang atau jasa yang tersedia dalam masyarakat, bagi keperluaan diri sendiri atau keluarganyaatau orang lain dan tidak untuk diperdagangkan kembali. Menurut KUH Perdata dimana orang alamiah yang mengadakan perjanjian tidak bertindak selaku orang yang menjalankan profesi atau perusahaan (Ariyadi 2018).

Pengaturan hukum terhadap suatu perbuatan pelaku usaha kepada konsumen dalam jual beli daring termasuk suatu perbuatan yang dilarang bagi pelaku usaha, dimana diatur dalam Bab IV pasal 8 hingga pasal 17 Undang - undang Nomer 8 Tahun 1999 tentang Perlindungan Konsumen, ada tiga bagian dalam hal ini yaitu larangan melakukan kegiatan memproduksi , larangan untuk memasarkan dan sekaligus larangan bagi usaha periklanan (Zulham 2016).. Larangan bagi pelaku usaha dalam kegiatan produksi. Kelompok larangan yang pertama adalah larangan bagi pelaku usaha dalam kegiatan produksi yang diatur dalam pasal 8 UU Perlindungan Konsumen.

Jika dilihat dari ketentuan pasal 8 angka 1 UUPK menyatakan bahwa pelaku usaha dilarang memproduksi ataupun memperdagangkan barang atau jasa yaitu, tidak terpenuhinya ketentuan dalam peraturan perundang-undangan yang dalam hal inisesuainya dengan berat bersih, isi bersih (netto) dan juga jumlah pada label barang tersebut tidak sesuai dengan ukuran dan takaran yang sebenarnya. Disamping itu kondisi barang/jasa yang dinyatakan dalam label tersebut dinyatakan tidak sesuai dengan keterangan promosi penjualan barang ataupun jasa tersebut seperti tidak tercantumnya tanggal kadaluwarsa, tidak mengikuti ketentuan mengenai bagaimana barang atau jasa tersebut dinyatakan halal, tidak tercantumnya label yang berisikan penjelasan tentang nama barang, berat atau isi bersih (netto), aturan pakai, tanggal pembuatan barang/jasa, akibat/efek samping, alamat pelaku usaha serta penjelasan lain yang menurut ketentuan harus dicantumkan sesuai dengan ketentuan peraturan yang berlaku.

\section{Sanksi Pidana yang Dijatuhkan terhadap Pelaku Tindak Pidana Penggelapan dalam Situs Jual Beli Daring}

Keberaadan pengaturan sanksi pidana diposisikan sebagai tahapan sanksi paling terakhir. Dimaksudkan didalam suatu undang - undang yang kesatu ada di atur yaitu sanksi administrasi, selanjutnya ranah hukum keperdataan barulah diatur tentang sanksi pidana. Hukum pidana sebagai obat terakhir, manakala sanksi - sanksi yang lain tidak dapat ditegakkan. Misalnya undang - undang tentang merek, undang - undang perlindungan konsumen, undang-undang psikotropika. Dalam perkembangannya tujuan pidana telah mengalami kemajuan yang disebabkan oleh ilmu tentang "Penologi" yang mempelajari pertumbuhan, arti dan manfaat pemidanaan, akan tetapi tidak menghilangkan sama sekali aliran - aliran "teori tujuan pidana" (Strafrechtheorieen) (Gunadi and Efendi 2016). Seseorang yang telah diputuskan dijatuhi hukuman penjara oleh hakim, berdasarkan ketentuan peraturan perundang-undangan dimana telah meniadakan sifat pidana dari pembalasan dan siksaan, serta mengganti dengan pidana bimbingan dan pembinaan. Ada anggapan bahwa seseorang sejak diputus bersalah oleh hakim, sifat pembalasan dan siksaan telah selesai dan dilanjutkan dengan pidana pembinaan dan bimbingan. Seiring dengan perjalanan waktu tujuan pidana telah mengalami 
kemajuan, pekembangan selanjutnya adalah tujuan pidana Indonesia, yaitu "supaya kebijakan hukum pidana harus berorentasi pada tujuan perlindungan sosial (social defene)." Konsep tentang social defene modern tidak hanya memperhatikan perlindungan terhadap masyarakat, tetapi termasuk juga pembinaan dan rehabilitasi pelakunya.

Tujuan pidana dan hukum pidana yang hanya berorentasi pada perlindungan masyarakat untuk mencapai kesejahteraan sosial (konsep tradisional dari social defence) merupakan pendekatan sepihak. Ketentuan tentang penggelapan dan pencurian di atur lebih lanjut dalam pasal Pasal 362 KUHP. Jika dilihat dari segi perbuatan yang dilakukannya tidak berasal dari pelaku dan terlebih dahulu harus direncanakan, dari pada penggelapan dari segi perbuatannya sudah terlebih dahulu diketahui . Dalam KUHP kejahatan kategori penggelapan dirumuskan atas lima model merupakan kesatuan kejahatan penggelapan yang penting, selanjutnya model tindak pidana penggelapan yang bersifat ringan, lalu model kejahatan penggelapan berdasarkan unsur yang menitikberatkan, dan selanjutnya model tindak pidana penggelapan dengan diwakilkan oleh seorang wali, serta model kejahatan tindak pidana penggelapan terhadap suatu lingkungan keluarga. Adapun unsur yang dapat pada ketentuan pasal 372 KUHPidana terdapat usur obyekif dan subyektif, dimana subyektif adalah suatu tingkahlaku yang berisikan arti memuat ketentuan peraturan yang ada berdasarkan unsur.

Tujuan untuk diadakan pidana dan perkembangannya di Indonesia dimaksudkan sebagai salah satu usaha untuk mencegah atau menanggulangi kejahatan dimana hampir semua Negara menggunakan aturan pidana untuk mencegah dan memberantas kejahatan. Mengenai hal ini dikenal beberapa teori pidana terdiri atas (Yahman 2016):

1. Teori pembalasan (Absolut / Vergelding theorieen);

2. Teori tujuan (Relatif theorieen doeltheorieen); dan

3. Teori gabungan yang dikenal dengan (Verenigingstheorieen)

Ketentuan mengenai kekuasaan mutlak pengaturannya tercantum didalam Undang-undang Dasar Republik Indonesia Tahun 1945 perihal perbuatan yang dapat di pidana. Pada aturan yang berlaku, menentukan setiap individu memiliki hak agar pencabutan tuntutan, berdasarkan aturan yang terterap secara tidak efektif keberlakuannya untuk menjamin keberlakuan aturan tersebut. Adanya perbuatan pidana hendak berdasarkan perbuatan seseorang. Hal tersebut tidak berdasarkan pada suatu tanggungjawab, peraturan perundang - undangan hal inidisertai ancaman pidana bagi sipembuatyang dipakai sebagai dasar untuk menjatuhkan pidana berdasarkan satu asas yang disebut degan asas legalitas. Dalam beberapa pasal yang berkaitan dengan Pidana Penggelapan yaitu Pasal 376.

Model perbuatan penggelapan dikarenakan oleh beberapa sebab factor pendukung, misalnya jika perbuatan penggelapan merupakan tergolongpada bagian kejahatan sebagaimana KUHP (buku dua). Perbuatan Penggelapan tergolong dengan modelkejahatan pada harta benda. Faktor - faktor yang menyebabkan terjadinya tindak pidana penggelapan berdasarkan data yangdiperoleh secara umum dimana pertama, mentalitas yang buruk merupakan salah satu faktor yang menimbulkan terjadinya tindak pidana penggelapan. Pegawai yang tidak kuat mentalnya maka akan mudah terpengaruh untuk melakukan tindakan yang sesuai dengan harkat dan martabat pegawai sebagai petugas. Sebaliknya pegawai yang bermental kuat tidak dapat dipengaruhi oleh adanya kesempatan atau peluang melakukan penggelapan. Pegawai yang mendasarkan diri pada pengabdian menganggap bahwa jabatan adalah amanah sehingga tidak akan melakukan penggelapan walaupun ada kesempatan. Yang kedua faktor pemenuhan kebutuhan hidup yaitu adanya tekanan keluarga untuk memenuhi kebutuhan hidup dan karena pengaruh gaya hidup yang komsumtif bisa mendorong seseorang untuk melakukan pengeluaran anggaran yang melebihi atas kemampuannya dan yang ketiga adanya niat dan kesempatan dimana niat dan kesempatan merupakan faktor pendorong timbulnya tindak pidana penggelapan yang disepakati oleh sebagian dari informan objek penelitian.

Betapapun besarnya niat jika tidak ada kesempatan penggelapan tidak dapat dilakukan dan sebaliknya jika tidak ada niat melakukan penggelapan dikarenakan mentalitas yang baik namun ada kesempatan maka penggelapan tidak dapat dilakukan. Sifat tamak dari manusia dimana kemungkinan orang melakukan tindak pidana penggelapan bukan karena orang tersebut miskin atau penghasilannya tidak cukup kemungkinan orang yang kaya akan tetapi masih punya keiinginan untuk memperkaya diri sendiri. Unsur penyebab tindak pidana penggelapan seperti itu datang dari dirinya sendiri. 


\section{SIMPULAN DAN SARAN}

\section{Simpulan}

Simpulan dari penelitian ini, yakni:

1. Pelaku usaha adalah setiap orang-perorang atau badan usaha, baik yang berbentuk badan hukum maupun bukan badan hukum yang didirikan dan berkedudukan atau melakukan kegiatan dalam wilayah hukum negara Republik Indonesia, baik sendiri maupun bersama melalui perjanjian menyelenggarakan kegiatan usaha dalam berbagai bidang ekonomi. Jual beli daring adalah transaksi yang dilakukan oleh dua belah pihak tanpa bertemu langsung untuk melakukan negoisasi dan transaksi jual beli yang dilakukan melalui alat komunikasi seperti chat, telfon, sms, web dan sebagainya. Larangan bagi pelaku usaha dalam kegiatan pemasaran yaitu Kelompok larangan yang selanjutnya adalah larangan bagi pelaku usaha dalam kegiatan pemasaran. Hal ini diatur dalam Pasal 9 ayat 1 Undang - undang Perlindungan Konsumen melarang pelaku usaha menawarkan, mempromosikan, mengiklankan suatu barang dan/atau jasa secara tidak benar atau seolah - olah barang tersebut telah memenuhi dan memiliki potongan harga, harga khusus, standar, standar mutu tertentu, gaya atau mode tertentu, karakteristik tertentu, sejarah atau guna tertentu, barang tersebut dalam keadaan baik atau baru, barang dan jasa tersebut telah medapatkan atau memiliki sponsor, persetujuan, perlengkapan tertentu, keuntungan tertentu.

2. Perbuatan pidana penggelapan berdasarkan ketentuan pasal $372 \mathrm{kuhp}$, dimana mengartikan seseorang yang mempunyai barang seseorang dengan maksud melanggar hukum merupakan perbuatan pidana penggelapan, sehingga dengan mudah orang mengatakan bahwa penggelapan merupakan opzettelijk delict atau delik sengaja semantara itu unsure objektif terdiri dari Pertama barang siapa seperti yang telah di paparkan dalam tindak pidana pencurian, kata "barang siapa" ini menunjukkan orang apabila seseorang telah memenuhi semua unsur tindak pidana penggelapan maka dia dapat disebut pelaku atau dader. Tujuan untuk diadakan pidana dan perkembangannya di Indonesia dimaksudkan sebagai salah satu usaha untuk mencegah atau menanggulangi kejahatan dimana hampir semua Negara menggunakan aturan pidana untuk mencegah dan memberantas kejahatan.

Saran

Saran dari penelitian ini, sebagai berikut:

1. Bagi pemerintah dalam hal ini sebagai pejabat berwenang, maka wajib untuk mengkaji ulang dari adanya ketentuan pasal dalam KUHP terkait sanksi pidana, agar segala sesuatu bentuk tindak pidana penggelapan dapat teratasi tanpa adanya suatu kendala dan setidaknya dapat terminimalisir;

2. Bagi Produsen sebagai seorang penjual hendaknya bersikap jujur dalam memasarkan suatu produk kepada konsumen, apabila hal tersebut kian terjadi maka dapat mencemarkan nama baik negara Indonesia;

3. Bagi masyarakat sebagai konsumen hendaknya berhati-hati dalam memilih suatu produk dalam situs jual beli daring, dikarenakan banyak terdapat akun-akun yang memasarkan produkproduk yang dapat merugikan konsumen dengan jumlah harga yang terbilang cukup murah.

\section{DAFTAR PUSTAKA}

Ariyadi. 2018. Jual Beli Online Ibnu Taimiyah. Cetakan Pertama. Yogyakarta: Diandra Kreatif.

Diantha, Pasek. 2016. Metodologi Penelitian Hukum Normatif Dalam Justifikasi Teori Hukum. Cetakan

Tiga. Jakarta Timur: Prenadamedia Group.

Gunadi, Ismu and Jonaedi Efendi. 2016. Hukum Pidana. Cetakan Kedua. Jakarta: Prenadamedia Group. Kotler, Philip. 2002. Manajemen Pemasaran, Analisis, Perencanaan, Implementasi Dan Kontrol. Bandung: Erlangga.

Soekanto, Soerjono and Sri Mamudji. 2018. Penelitian Hukum Normatif Suatu Tinjauan Singkat. Cetakan De. Jakarta: Rajawali Pers.

Syawali, Husni and Neni Sri. 2000. Hukum Perlindungan Konsumen. Cetakan Pe. Bandung: PT. Mandar Maju.

Yahman. 2016. Karakteristik Wanprestasi Dan Tindak Pidana Penipuan Yang Lahir Dari Hubungan 
Kontraktual. Cetakan Tiga. Jakarta: Kencana.

Zulham. 2016. Hukum Perlindungan Konsumen. Cetakan Ke. Jakarta: Kencana. 